\title{
Negro Librarians in Predominantly Negro Colleges
}

\begin{abstract}
A survey was made of Negro librarians in predominantly Negro colleges in an effort to determine their backgrounds and attitudes toward their profession. More than one-third of the eighty-eight respondents had graduated from Atlanta University's library school. Their previous work experience and their reasons for going into library work are probed, as well as their like or dislike for their work.
\end{abstract}

\section{$\mathrm{T}$}

HE NEED for trained librarians in a profession where the supply cannot meet the demand, concomitant with the Civil Rights Act, has caused many libraries to cast scouting eyes for prospective Negro librarians. To some employers these also served to present a "show piece" of good faith where federal funds were being sought to gird sagging budgets, and as balm to soothe overzealous liberals.

But to the consternation of the seekers, Negro librarians are in a decided minority. Negroes have been slow to enter this field for several reasons. Most Negro college students find it a financial hardship to pursue even a four-year college program. For them to continue further study in a field notorious for its low pay in lieu of a teaching position or any other endeavor requiring less preparation and offering better salaries would be hardly feasible. Facing hard facts, jobs too often have been limited to Negro librarians, particularly in the South. Positions were available only in segregated school systems and branch libraries located in Negro neighborhoods.

Possibly an important historical factor in there being too few Negro librarians

Mrs. Shockley is Associate Librarian of Maryland State College in Princess Anne. has been the lack of training schools for this purpose. The first effort specifically to train Negroes for library work was initiated in 1905 by the Louisville free public library. "This apprentice class is the first example of any attempt in the South to provide library training for the prospective Negro librarian. That it served a need of the time is evidenced by the fact that other cities, such as Houston and Memphis, sent their Negro branch librarians to Louisville for their professional education."

It was also distressing that no other school was established for training $\mathrm{Ne}$ groes until the opening of the Hampton library school through a Carnegie grant in 1925. This school, offering the BSLS degree, trained many pioneer and noted Negro librarians, some of whom later went on to the master's program. Unfortunately, because of financial difficulties, the school was phased out in June 1939.

Not until 1941 was the Atlanta University school of library science founded by a Carnegie grant. During the same year, a school of library service was established at North Carolina College, but it is not yet accredited by ALA.

${ }^{1}$ E. A. Gleason, The Southern Negro and the Public Library (Chicago: Univ. of Chicago Press, 1941), p. 23. 
Because of such factors as these, it is obvious that Negroes have been slow to embark into library work because of the above mentioned inequities and problems relating to them.

This survey was conducted to obtain a glimpse of present-day Negro librarians-their backgrounds and attitudes toward a profession now changing with respect to them. Questionnaires were mailed to twenty-five predominantly Negro colleges. The schools were both state and private institutions accredited by their regional accrediting associations, with an enrollment of five hundred or more students, and having a library staff of three or more librarians.

Of these schools, seventeen responded with combined staffs of eighty-eight respondents. Seventy-five of the librarians were female and thirteen were male. The predominance of females can be attributed to the field being looked upon as a "female" occupation and also because there are more Negro women college graduates than men. One of the females in the survey held a PhD degree, while another had a master's degree in English as well as one in library science.

Eighty-three of the respondents had graduate degrees in librarianship with three having BSLS degrees from the Hampton library school. Two were working toward advanced degrees at Atlanta University and Indiana University.

Listed below are the library schools from which degrees were awarded and the number of graduates from the schools:

Atlanta University

University of Illinois

University of Michigan

North Carolina College

Western Reserve University

Columbia University

Syracuse University

George Peabody

University of Oklahoma

Drexel Institute

Catholic University
Carnegie Library School (Now University of Pittsburgh)

Louisiana State

North Texas State University

Rutgers

Simmons

University of Chicago

University of Kentucky

University of Pittsburgh

University of Wisconsin

Besides 37.34 per cent of the graduates receiving degrees from a predominantly Negro library school, eighty-five of the respondents did their undergraduate work at predominantly Negro colleges. North Carolina College and Central State University had the highest number of graduates in the survey to enter the profession.

It is conjectural that Negroes attend predominantly Negro library schools for the same reasons they did for undergraduate work. It has been difficult for Negroes to get into white graduate schools because of finances, academic requirements, and race. It is also true that some Negroes simply prefer going to predominantly Negro schools. And since most Negro colleges are located in the South, many are already settled there and can earn degrees on a part-time basis.

Graduate study is expensive and timeconsuming, and only twenty-five of the respondents entered library school immediately after completion of their undergraduate work. Diverse previous occupations were listed with public school teaching being foremost. Working in a library followed, with other former employment listed as insurance work, college payroll clerk, stenographer, factory work, YWCA worker, bookstore manager, and duty with the armed services (which included one female).

The reasons given for entering the library profession were: (1) interest in books; (2) interest in people; (3) a librarian's influence; (3) dislike of teaching; (4) availability of jobs. Members of 
the families of fourteen of the respondents were librarians.

One librarian remembering the dual structure of segregation which has tragically separated Negroes and books stated:

I grew up in a segregated community in which I was denied access to the public library. My reading interests and mental curiosity were never completely satisfied in the meager school library which was available to me during the school term.... Therefore, I decided, while still a child, to become a librarian in order to remove barriers between books and me.

The fact that the availability of jobs in the field was least influential is interesting since Negroes are likely to find it difficult to obtain employment in many areas. Apparently Negro librarians are essentially bookmen quietly dedicated to the profession.

Eighty-seven of the librarians liked their work with the one negative response attributed to "long hours and poor pay." The reasons for liking their work included: (1) personal satisfaction; (2) fondness of books and knowledge; (3) opportunity to help others; (4) challenging and interesting; (5) rewarding and informative.

Answers to the question of whether they think there is little discrimination now in hiring practices in predominantly white colleges and universities were:

$\begin{array}{ccc}\text { Yes } & \text { No } & \text { Don't KNow } \\ 57 & 14 & 17\end{array}$

As to why they thought there is less discrimination in employment practices, some felt the trend now is toward what a person can contribute rather than race. Also cited were the need for librarians and better trained personnal, antidiscrimination laws, and the necessity for "show" Negroes. An indication that white academic circles are hiring more Negro librarians was offered by one librarian from a predominantly Negro college in a North-Central state who noted that there were ten surrounding colleges with Negroes on their staffs. Other librarians had seen more Negro librarians representing predominantly white institutions at professional meetings. Job overtures had been made to one.

A negative response offered: "I have had experience in applying to a predominantly white college where my application was held until an opening was available. Later, many white librarians were hired, some with less experience and training than I." Another surmised that it appeared hiring practices and attitudes were basically unchanged.

Since most Negro college librarians work in predominantly Negro institutions, they were polled as to if they preferred working in a Negro college.

$\begin{array}{ccc}\text { YES } & \text { No } & \text { INDIFFERENT } \\ 10 & 11 & 67\end{array}$

Those who would rather work in Negro colleges gave varying reasons. Several felt they would be of more service working with Negro students who need more elementary exposure to the resources of library materials, and that Negro colleges have a greater need for trained and competent people than white colleges which have more resources to draw upon. One gave personal and social reasons.

The respondents who did not prefer working in a predominantly Negro college wanted to feel as "qualified librarians who can work in any situation." Others felt that the contact would broaden their thinking by knowing different people.with various cultural backgrounds, and some wanted to have experience in both situations.

The prevailing number of indifferent replies showed an over-all liberal-mindedness in regard to the profession and race as a whole. Such answers as: "The philosophy of the institution and quality are more important to me than the par- 
ticular racial make up of the institution." The giving of services was presented as more important than the place of service or race factors. These too in their indiscriminate attitude believed that people were people, and were indifferent to color, character, or temperament.

The librarians secured their positions in the colleges by (1) forty-one applying directly to the college; (2) twelve through a friend; (3) library school placement by six; (4) twenty-nine not indicating.

To the question of salaries being adequate for librarians in the colleges:

$\begin{array}{ccc}\text { YES } & \text { No } & \text { No ANSWER } \\ 6 & 74 & 8\end{array}$

The study in essence indicates that Negro librarians are in a minority because of the historical background of a society long operated on a dual pattern of segregation. Negro librarians have been thwarted in this field (as in others) because of the lack of training opportunities and unfair employment practices accompanied by other imparities embedded in a separate-but-equal society.

Negro librarians do not wish to be considered a different breed of people, but want to be thought of as librarians first. They feel confident and are eager to perform in any job situation.

With college libraries housing the free thoughts of man in relation to himself and society, it should be especially true in this environment that all men should be represented. Because of current trends and changing attitudes, Negro librarians are looking forward to broader avenues to occupational achievement and fufillment than have existed in the past. Books do not know of discrimination-neither should libraries.

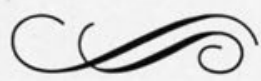

